\title{
MATERIALISM AS SEEN IN THE BLACK TULIP BY ALEXANDRE DUMAS
}

\author{
Meta Kurnia Sari
}

\begin{abstract}
This study aims to observe the Materialism among the main characters in Alexandre Dumas' novel, The Black Tulip. In the research process, the writer finds the data by reading books which related to the topic as well as the through the internet.

This study basically adopts "Dynamic Structuralism" which includes three elements; the reader, the work, and the reality. The method of research is conducted through library research, with The Black Tulip as the primary data, and the references that support the analysis as the secondary data.

The result of this study shows that the materialism exists in everyone. People need money in order to support their life. Money is indeed important and it is employed as the parameter of success in some aspects of life. However, the level of materialism in every single person is different. This paper shows how significant a black tulip is for certain main characters, including the ways they treat it. It is also the symbol of sadness in the Netherlands in 1672-1673 which was identical with the dark age. Besides, it is also as the symbol of Rosa, the prison keeper daughter who helps Van Baerle in revealing the truth over the black tulip.
\end{abstract}

Keywords: materialism, the Netherlands, black tulip, money, Van Baerle.

\begin{abstract}
ABSTRAK
Penelitian ini berutujuan untuk menelaah materialism pada tokoh utama yang terdapat pada novel Alexandre Dumas yang berjudul The Black Tulip. Pada proses penelitian, penulis mengumpulkan data dengan membaca buku-buku yang berhubungan dengan topik dan juga melalui internet.

Penelitian ini pada dasarnya mengadopsi teori "Dynamic Structrturalism" yang meliputi empat unsur; pembaca, karya, dan kenyataan. Metode penelitian yang digunakan ialah penelitian pustaka, dengan novel The Black Tulip sebagai sumber data utama, dan beberapa referensi yang mendukung analisis sebagai data sekunder.

Hasil penelitian ini menunjukkan bahwa sifat materialisme terdapat pada setiap orang. Manusia membutuhkan uang untuk mendukung kehidupannya. Uang pada dasarnya penting dan digunakan sebagai tolok ukur kesuksesan dalam beberapa aspek kehidpan. Bagaimanapun juga, tingkat sifat materialisme pada setiap orang berbeda-beda. Penelitian ini menunjukkan betapa pentingnya setangkai bunga tulip tulip hitam untuk beberapa tokoh utama, termasuk cara mereka memperlakukannya. Tulip hitam juga sebagai simbol kesedihan di negara Belanda pada tahun 1672-1673 yang identik dengan tahun kegelapan. Selain itu, tulip hitam juga merupakan simbol Rosa, anak penjaga penjara yang membantu Van Baerle dalam mengungkap kebenaran bunga tulip hitam.
\end{abstract}

Kata kunci: materialisme, Belanda, tulip hitam, uang, Van Baerle. 


\section{INTRODUCTION}

Certain people express their ideas through literature. "Literature is a social institution, using as its medium language, a social creation. Such traditional literary devices as symbolism and metre are social in their very nature" (Warren and Wellek, 194). There are some literary works that reflect the society at a particular period of time. Many authors have written certain works related to the history of a particular place or country as well. Alexandre Dumas is one of the authors who wrote a reflection of a particular society in the Netherlands in the form of a novel entitled The Black Tulip.

Besides The Black Tulip other novels of his novels include The Count of Monte Cristo and The Three Musketeers. "The Black Tulip is originally published in three volumes in 1850 as La Tulipe Noire by Baudry (Paris)". (http://www. answer.com/topic/the-black-tulip). Through The Black Tulip, Alexandre Dumas tells the readers about romance, history as well as materialism. He mixes these three components in order to create such a great novel which tells the readers a story. The historical background is the Netherlands around 1672 and 1673, while the love story is between Rosa, the prison keeper's daughter and Cornelius Van Baerle, the tulip fancier who is imprisoned. In this novel, the main characters are influenced by the material things.

The writer of this paper finds Alexandre Dumas' The Black Tulip allusive, challenging, and interesting because it presents materialism behind a love story and the history of the Netherlands during 1672 and 1673. Also, the writer appreciates Dumas' solemn writing style, he effectively describes the efforts of the characters in pursuing material things, at the same time as Dumas also depicts an exact era of that historical era perfectly that is in 1672 and 1673 . He criticizes certain politicians and other Dutch people in 1672 and 1673 throughout the novel, for example, the murder of Cornelius and John De Witte in 1672. His judgment toward what is wrong and what is right is clear as well in the novel.

In addition, there are some parts of the novel which are interesting to be analyzed further, such as the symbol of a black tulip which is mentioned behind the love story. Besides, the writer of this paper considers that analyses of Dumas' The Black Tulip are rare since it was written in French while the setting is in the Netherlands in 1672 to 1673. The writer of this paper finds it challenging to deal with this particular work because some of the events described in it happened in real life in 1672 and 1673. However, since it has been translated into English and it has to do with European studies and history, the writer considers that The Black Tulip by Alexandre Dumas needs to be analyzed further in order to open up the horizon of Indonesian understanding on European cultures, history, and studies.

The primary objectives of this study are:

- To examine the materialism in The Black Tulip, to expose more that Isaac Boxtel is materialistic.

- To show all main characters' different intentions of money and the black tulip.

- To observe the significance of the black tulip in the novel.

- In line with the objectives of this paper, the focus of examination is the 
strong orientation on materialism in The Black Tulip by Alexandre Dumas. As it is mentioned by Kenney,

Any discussion of character in fiction, then, must attend to the relationship between character and the other elements of the story, and between character and the story as a whole. That is, character must be considered as part of the story's internal structure (Kenney, 26).

Thus, it has something to do with the characters in the novel, such as Van Baerle, Rosa, and Isaac Boxtel, and Gryphus.

Since this paper examines materialism in The Black Tulip, the setting of which takes place in the Netherlands, the scope of the study covers the history of the Netherlands during 1672 and 1673 as well as prominent figures in the Netherlands during that era including main characters' behavior towards materialism, commentary criticism of the work, and materialism.

This analysis is about the materialism as observed in The Black Tulip. Besides the analysis of the novel itself, and description of setting of time and place of the novel, as well as a commentary on the novel are important. Thus, the dynamic approach is appropriate since it covers the elements above. Mukarovsky as it is cited in Fokkema and Kunne-Ibsch about dynamic structuralism mentions that "the work of art manifests itself as sign in its inner structure, in its relation to reality, and also in its relation to society, to its creator and its recipients" (Fokkema and Kunne-Ibsch, 143). Since materialism cannot stand by itself, dynamic structuralism is appropriate to be applied in this paper.

The primary source of this paper is the novel The Black Tulip. Library research was carried out to collect the data related to the novel The Black Tulip. In order to support the main data, the writer of this paper refers to other books, material, and sources related to its analysis. To support and give a clear picture of the work, it is necessary to explore more about historical and cultural background in the Netherlands around 1672 and 1673 as well as brief note on The Black Tulip.

There has been a study about The Black Tulip by Alexandre Dumas. This particular research examines the historical events of that particular novel, its political setting, and the ambition of several characters. This particular paper looks at the cultural elements of the novel, including the wave of 'tulip mania' that swept Holland during this time period. (Essaytown)

According to the best of the writer's knowledge, there has not been any research yet about The Black Tulip by Alexandre Dumas at the Library of Faculty of Cultural Sciences Universitas Gadjah Mada. Since there is a paper on www.essaytown.net analyzes The Black Tulip, this paper is going to analyze the materialism in relation with the main characters of the novel as well as the significances of the black tulip which makes it different from the previous research.

\section{Materialism in the Main Characters of the Novel}

Materialism as Seen in Each Main Character

\section{Isaac Boxtel}

Isaac Boxtel is Van Baerle's neighbor who is also a tulip fancier. $\mathrm{He}$ is not as wealthy as Cornelius Van Baerle, he is not as great as Van Baerle in growing tulips and he is not 
as famous as Van Baerle. Everytime he does is trying to fall Van Baerle down by creating some obstacles to Cornelius Van Baerle.

He even bought a telescope in order to see what Van Baerle does at his house related to the tulips. His madness of fame and wealth drives him mad and it triggers him to do the bad things to Van Baerle.

He therefore bought a telescope, which enable him to watch, as accurately as did the owner himself, every progressive development of the flower, from the moment when the first year, its pale seed-leaf begins to peep from under the ground, to that glorious one when, after five years, its petals at last reveal the hidden treasures of its chalice ( $p$ 63).

Isaac Boxtel is obsessed to be as rich as Van Baerle and as successful as Van Baerle in cultivating tulips. When he knows the announcement of the competition to grow black tulip, the will of pursuing the a hundred thousand guilders is getting crazier and crazier. He puts his all his effort to beat Van Baerle down. Therefore, he has no more enemies in growing tulips.

What is seen related to materialism ideas of Van Baerle is different from Rosa and Isaac Boxtel. Isaac Boxtel finds by getting the black tulip which can be stolen from Van Baerle can lead him to a hundred thousand guilders. He believes that by having the black tulip he will be such a rich man since he is not from a wealthy family. Therefore he is willing to pursue Van Baerle and claims himself as Jacob Gisel coming to the prison in The Hague.

He succeeds in putting Van Baerle in jail; he succeeds in spreading the rumor that Van Baerle is keeping a great secret from John and Cornelius De Witte. He thinks that Van Baerle will be murdered the same as the De Witte brothers. He is sure that he will not have any rival after all and he can get a hundred thousand guilders. He forgets what his own duty is. He keeps minding Van Baerle's business rather than taking care of his own tulips. Due to minding other's business he forgets to take care of his tulips. The progress of Van Baerle in cultivating tulips hurts him very much.

In fact, the bulbs are not Isaac Boxtel's, they are produced by Van Baerle and are cultivated by Rosa. However, the will of having such great masterpiece though they are not his blinds him and it leads him to do some bad deeds to Van Baerle. In fact, Isaac Boxtel is a hard-worker; he works so hard to get what he wants, the grand black tulip and a hundred thousand guilders. However, he does the wrong things in pursuing material things based on society; that is stealing others' belongings.

Isaac Boxtel is also a tulip-fancier and it is natural that he wants to achieve the best among tulip-fanciers. Moreover, the one who succeeds in growing a grand black tulip will be honoured one hundred thousand guilders. He wants the money so much. Thus, he puts all his effort to get black tulip bulbs and get rid of Van Baerle. He sees clearly what Van Baele does in the dry-room, "Leaving Dort, Mynheer Isaac Boxtel had abandoned not only his house, his servant his observatory, and his telescope, but also his pigeons ( $p$ 120). Just because of his envious character toward his neighbor, Isaac Boxtel is willing to abandon almost all of his belongings in order to get rid of his rival and for the sake of the black tulip. He does not care about anything but the bulbs of black tulip owned by Corne- 
lius Van Baerle. He does this way because the grand black tulip will be granted a hundred thousand guilders. Therefore Boxtel is considered as a money-oriented materialistic person based on the level of the materialism. Moreover, he does not consider anything including moral either religion or moral value. For instance, he steals the black tulip from Van Baerle because he could not produce it himself. He even tries to get rid of Van Baerle by telling the government that Van Baerle has been involved in political secret of the De Witte brothers.

Boxtel also keeps watching what Rosa does in her room related to the tulip by renting an attic in Loevenstein in order to ease him getting the black tulip. Once, Boxtel is trying to make sure that Rosa is leaving the room, thus he takes the flower. After he had stolen the black tulip and he ran away to Haarlem in order to make a false report that he finds the black tulip. As it is stated in the novel, Boxtel is also such an expert in doing criminal. $\mathrm{He}$ does some actions which are guilty enough to be put in prison for the sake of a black tulip which will be granted a hundred thousand guilders. He also creates some false facts in order to make sure that he is the great tulipfancier.

However, when he keeps telling lies, he gets trapped by a question of Rosa about where he kept another bulb of the black tulip and the amount of money, but he tries to answer Rosa, "I have it at home" (p 214). When Boxtel is asked where he kept the other bulb, he answered that it was in his house in Dort. It is totally wrong when he mentions this particular lie since Rosa can prove that she brings the bulb. Moreover, Boxtel gets cornered when Rosa mentions and tells the chronology of how Boxtel has stalked her as well as her efforts in growing and maintaining the black tulip.

It is the proof that the tulip is not produced by Isaac Boxtel and it is also the proof that Boxtel is such a materialistic man who wants to take over someone achievement. "Boxtel, crushed by the failure of his hopes, lay senseless on the ground. When they raised him, and examined pulse and his heart, he was quite dead" ( $p$ 246). Finally Isaac Boxtel died because of his failure. He wants to possess what he does not achieve by stealing it from other person. People may do anything in order to pursue what they want including money. However, moral needs to be considered in this case. Boxtel puts all his effort to do so, however he forgets understanding what is wrong and what is right based on morality in society as it is mentioned by Fried,

Our first moral duty is to do right and to avoid wrong. We must do no wrong-even if by doing wrong, suffering would be reduced and the sum of happiness increased. Indeed we must not do wrong even in order to prevent more, greater wrongs by others. If those others do wrong it is their wrong for which they are responsible, this concept of personal responsibility leads to an account of moral choice and of substantive moral values that is rich, complex, and true to the facts. Central to this account is the individual's capacity to choose freely and effectively, to choose between right and wrong (Fried, 2).

Isaac Boxtel, in this case does not consider what is right and what is wrong by society related to the moral value. Therefore he is judged indirectly by the society he cannot help himself. He does this way because of 
his materialistic attitude which had led him to do several bad deeds including stealing Van Baerle's black tulip.

\section{Cornelius Van Baerle}

Cornelius Van Baerle is a round character and the central one in the story. He represents high class society because he is a rich man and it seems that he does not need to work in order to obtain some money. $\mathrm{He}$ quits being a doctor then he devotes his life to be a tulip-fancier in Dort. It is known that tulip-fancier during the time was a prestigious profession. His life-concern is tulips, although the protagonist, Dumas uses him as the tool to become the 'victim' in the story.

His father tells Van Baerle that in life people have choices and he points to his good friends Johann De Witte and Cornelius De Witte (the De Witte brothers) who were politicians during that era, who experienced some consequences that arose from their choices as politicians. Van Baerle takes it as a lesson, he does not want to be either a politician like the De Witte brothers or a wealthy merchant like his father. It is because those occupations have some risks, according to him. Indeed, being a tulip-fancier is a very prominent hobby as well as an occupation which earns some money during this period of time. His life is centered on tulips growing and producing new varieties of tulips. In the novel, Van Baerle is very busy with himself. He is trying to make himself happy with his own way.

$\mathrm{He}$ tries to produce the black tulip as his show of love to the tulips and above his ability in cultivating tulips. However, Van Baerle is considered materialistic that is materialistic based on human basic need. This trait is owned by certain people since money is important in life. Yet, people who have this certain trait still consider religion, art, as well as moral beliefs in doing some efforts in order to obtain money. Van Baerle in this case tries hard to produce the black tulip in order to get the recognition as well as money for the poor of Dort and tulip cultivation without ignoring several laws in aesthetic, religion, and moral values. He produces some new varieties of tulips, he grows them, and joins the competition for money as well as recognition. Yet, most human beings need money in life. Basically, human beings have several degrees of ambition in pursuing money. Yet, they have different ways of pursuing material things.

His attempt to pursue material items has some obstacles. These obstacles are beyond his control. One of them is Isaac Boxtel, his envious neighbor, who is also a tulip fancier. Because of the suspect that he has a relationship with the De Witte brothers who were executed and suspected as enemies of the country, he is put in jail because Isaac Boxtel tells the government. He tries to avoid problems. He considers the De Witte brothers had experienced murder over political conspiracy as a consequence. Van Baerle also reflects on his father as a merchant has some problems. Furthermore, he quits being a doctor to avoid problems. Therefore, he picks a profession as a tulip-fancier to avoid problems.

Although he is put in prison, he still keeps the bulbs that he has been working on. He believes that those bulbs will grow black tulips. In fact, he gives up at the beginning but then, the presence Rosa; the prison keeper's daughter encourages him. In growing the tulips another obstacle comes, that is, he is 
tried to be hung in front of the people of Holland. However, it is canceled and he is moved to another jail in Loevenstein. He is separated from Rosa but fortunately Rosa and his father also move in to the prison in which Van Baerle is in. At times, he is despondent but Rosa keeps helping him over and over. Finally, he wins the prize of one hundred thousand guilders and finally married to Rosa. The intense meeting between Rosa and Van Baerle creates romance between them. Van Baerle is a lonely man, as it is mentioned, "I am alone in this world; my parents are dead; I never had a sister or a brother. I have never had a thought of loving anyone with what is called love, and if anyone has loved me I have not known" ( $p$ 104). He strives to convince Rosa that he is alone. By saying several words, he hopes that Rosa understands him. He aims that Rosa understand that he may not treat Rosa in a special way since he is not experienced in being very close with other people.

As it is mentioned by Van Baerle that he is indeed alone, moreover at the age of twenty eight, he has not had any lover yet. His heart seems to be closed to the term of love. It seems to be such a reluctance if he loves someone due to what he has undergone in his life by telling that he has no parents, no sibling, no lover, and yet, no friend. That is why most of the compensation of his life goes to flowers and plants. It is normal as well for him that he leaves his occupation as a doctor and put plants and flowers as his hobby as well as duty. Although he does not need more money due to his money from the parents, he has flowers and plants as his 'friends', but then his socialization to the people outside, seems to be awkward. It can be seen that Van
Baerle has just relations with his godfather, Cornelius De Witte and his brother, John De Witte who are murdered by the people of the Netherlands. Van Baerle remains alone although the people who come and fro seeing the tulips bed, flowers as well as plants in his house do not know him personally.

Yet, there are some proofs that Cornelius Van Baerle is not too materialistic. Some lines in the novel show that Van Baerle applies money as the support. It is of course different from other characters in the novel. The materialism which exists in Van Baerle is actually considered as normal since he pursues what is deserved him. However, he still puts tulips over the money.

When he is about to be hung in a scaffold and he still thinks of the bulbs of the black tulip which are supposed to be granted a hundred thousand guilders and recognition. When someone is about to die, what he cares is himself, not the belongings he has. It is totally different from Cornelius Van Baerle. He still thinks of his belonging, that is a black tulip. It also shows that he has a kind of fear of losing a black tulip.

"I have only to say that I wish you to preserve these bulbs as the most precious treasure, and carefully to treat them according to the directions I have given you! Do it for my sake; and now farewell, Rosa" ( $p$ 107). Those words again contain tulip and bulb aspects. It seems that although Van Baerle is willing to be hung in a scaffold, he does not seem to be willing to be apart from his bulbs, which are supposed to produce a black tulips and it will be granted a hundred thousand guilders from the Horticulture Society of Haarlem. He keeps on saying the same statement about 
to preserve the black tulips to Rosa. He even treats the black tulips as the only belonging he has in this world.

However, Prince of Orange knows as William of Orange, the stadtholder of Holland stated that Cornelius Van Baerle is not guilty enough to be put into death sentence and it is too much to set him free either. Thus, Prince of Orange commands that Cornelius should be put into prison. In this postscript, William of Orange, Stadtholder of Holland, condemned Cornelius Van Baerle to imprisonment for life. He was not sufficiently guilty to suffer death, but he was too much so to be set at liberty ( $p$ 111).

That particular statement mentions that Van Baerle is finally free from the death penalty although he is not totally free since he will be imprisoned for the rest of his life. "Never mind, all is not lost yet; there is some good in the perpetual imprisonment; Rosa will be there, and also my three bulbs of the black tulip are there" ( $p$ 111). Van Baerle is not put into death, yet, he is still being imprisoned. The first which he thinks of is the bulbs of the grand black tulip. He is relieved when he realizes that he is already free from the death penalty, yet, he is still able to reach the bulbs of the black tulip which are now with Rosa. The proof that Van Baerle is materialistic gets clearer in this part. He feels safe when he mentions "all is not lost yet" ( $p$ 111). It seems that in his life merely consists of himself and his black tulip.

As it is clear in the novel that Van Baerle is not guilty, he does not do against the law. However, he is put in jail. It somehow is luck for him to meet Rosa but it is also a catastrophe for him to meet Gryphus. Gryphus is such a rude and cruel jailer who almost always does bad things to Van Baerle as a prisoner. Gryphus is Rosa's father. Money here is not for Van Baerle. He tries to support Rosa that the money will be for her. That amount of money is not that much for him, but it will be valuable for Rosa who is not rich.

The happiness of Van Baerle hearing from Rosa that she is able to take care of the bulbs turns out into a fear. Van Baerle feels like that there is something like a threat when Rosa told him that someone named Jacob Gisel was spying after her when she was busy with the soil and the tulip. It surely bothers his mind. Then, Van Baerle feels that there are two threats for him, the first one is for the tulip and the second one is for Rosa. It is also the beginning that the tulip is being watched by someone. He does not know that the man who follows Rosa is follows the bulb of the black tulip. He is Isaac Boxtel whom Rosa and Gryphus know as Jacob Gisel.

The fear of Van Baerle is proven that Boxtel or Jacob Gisel comes over to Loevenstein for the sake of the black tulip. Finally Rosa appears to Van Baerle telling some information about the black tulip when she considered not to be mad at Cornelius anymore. He even gets paler knowing the information that his grand black tulip is in danger. It is clear that he is afraid of losing Rosa, yet he is much more afraid of losing his black tulip.

Van Baerle also mentions this particular sentence to attract and praise Rosa as she looks after the black tulip. "You are right, Rosa; it is your dowry, you know" ( $p$ 171). Even he mentions that it will be the dowry for Rosa and those words seems to be merely a lip-service, so Rosa gets happier and supportive in tak- 
ing care of the black tulip. Dowry represents the black tulip which will be granted a hundred thousand guilders. The happiness and optimism of Van Baerle turns out to be sadness when Rosa tells him that the black tulip is stolen. "Stolen, stolen, stolen; I am lost!" ( $p$ 189). He is lost and he considered himself to be lost. He loses the black tulip which will be granted a hundred thousand guilders. It means that he loses the money. He even has heart to make Rosa pursue a black tulip and take it back. Thus, he will get the money and recognition as the pioneer in discovering the grand black tulip.

When Rosa comes to Haarlem proving that Van Baerle is the real producer of the black tulip, some proofs are found that Van Baerle is not guilty. However, at that time, Van Baerle is still mad, moreover Gryphus comes over to his cell asking about Rosa and Rosa is not in Loevenstein. Gryphus is about to beat him but then he threatens Gryphus back. It is not usual that Van Baerle does this way unless he is too upset of losing his greatest treasure, the grand black tulip. There are some officers taking him to Haarlem. He finally sees black tulip and he is really amazed by that particular flower. It is a proof that he is really crazy of the black tulip not the money. Indeed it is normal since he discovers it and he finds it flower. "At the other, Cornelius, panting for breath, silent, and his attention, his eyes, his life, his heart, his love, quite concentrated on the black tulip" ( $p$ 244). It does not stop in that part, Van Baerle is startled when he finds that Rosa gets the recognition as the owner of the black tulip. He feels that Rosa betrays him. In this part, Van Baerle does not seem to take it for granted although Rosa who takes care of the flower, Rosa saves the bulbs; and Rosa who pursues the flower to Haarlem by herself."Oh! muttered Cornelius, she has then belied me, when she said this flower was stolen from her. Oh! that is why she left Loevenstein. Alas! am I then forgotten, betrayed by her whom I thought my best friend on earth?" ( $p$ 245). It hurts him deeper when he finds that Jacob Gisel is in fact Isaac Boxtel, his neighbor in Dort. He feels that some people have betrayed him; they are Rosa and Boxtel. However, finally Van Baerle is free because of Rosa.

\section{Rosa}

Rosa helps him a lot in taking care of bulbs of his black tulips. Once she meets the De Witte brothers and one of them gave her a book; that is a bible. However, she cannot either read or write. By seeing Van Baerle over and over when her father has slept, she can read and she can share thought to Van Baerle. They are finally falling in love to each other. Besides, Rosa is also as a tool for Van Baerle in fulfilling his materialism. She is the motor in the court that the black tulip belongs to Van Baerle with the presence of another bulb of the black tulip. She really appreciates the hard work of Van Baerle in growing such masterpiece in the form of the black tulip and she also appreciates herself in taking care of the black tulip. Therefore when the black tulip is stolen by Isaac Boxtel, she runs away to see the Prince of Orange and telling the truth that she is the real owner the black tulip at the beginning and telling the president of Horticulture Society and Prince of Orange that the black tulip is first grown by Van Baerle who is now in prison.

She is considered to be materialistic in a good way. She is considered as a materialistic person based on human basic need, as it 
is very natural to be materialistic as a human being; Rosa has that particular trait as well. Rosa tries to maintain and takes a good care of material thing. She pursues the material in order to save Van Baerle from the prison and to get the recognition that Van Baerle is the pioneer in discovering the black tulip, and he deserves to be granted a hundred thousand guilders and it has been promised by the president of Horticulture Society, Van Herysen.

In this story, Rosa can be a symbol of a black tulip. As most people know that tulip is a kind of flower cultivated in the Netherlands. This kind of flower has some colors, such as red, yellow, and some other bright colors. A flower also means a girl. Rosa is a girl of the Netherlands who is born and raised in a prison and she is a daughter of a prison keeper named Gryphus. Her mother passed away long time ago. She even cannot either read or write. Yet, she is young and beautiful. She is a beautiful young girl living in a prison. Of course her life is not as bright as other girls who live in freedom and have such good living. She spends most of her life in prison, seeing how the prisoners are abused. Those are the signs of darkness life of Rosa. Yet, she is beautiful as a flower but she has such an unpleasant life in jail. She has seen she darkness of the people who have been bullied by her father, as she says, "Yes, he has been harsh to you, but it is his nature; he is so to everyone, and you are not the only one whom he has bullied" ( $p$ 102).

She gets used to the surroundings in prison. Rosa, as a prison daughter, she falls in love with Van Baerle who is handsome and young. They meet in the prison when Van
Baerle is accused of being a secret keeper of Johan De Witte and Cornelius De Witte. In Rosa, materialism is more at her appreciation toward her love to Van Baerle; moreover, he is still young and he has bulbs of black tulip which will be granted a hundred thousand guilders. That is because Van Baerle trains her reading and writing at nine o'clock every night every time her father (Gryphus) has gone to bed. She goes down to Van Baerle's cell secretly. Every night, Van Baerle trains her to read and to write and eventually they fall in love to each other. Rosa knows about the black tulips and the bulbs kept by Van Baerle. Van Baerle trusts Rosa very much when he cannot do anything to the black tulip when he is in jail. Rosa is also willing to keep and maintain the black tulip. In the beginning Rosa is glad to help Van Baerle in keeping the black tulip since she falls in love with him. However, she is very disappointed and jealous when she finds that Van Baerle loves the flowers more.

Rosa is absolutely disappointed when she finds Van Baerle loves the black tulip more than he does to her. It is a form of natural jealousy of a girl toward something, in this case, a plant of a black tulip. It is natural because Rosa takes care of the black tulip until it flowers. She treats the flower as if it is her own child because she falls in love with Van Baerle. However, Van Baerle is not sensible enough that the attention to the flower given by Rosa is a form of her attention to Van Baerle as well. It seems that van Baerle is like counting the stars and he forgets that there is a moon, a beautiful moon called Rosa.

Rosa actually loves the black tulip and she has the materialistic attitude in her al- 
though it is different from Isaac Boxtel. When she finds out that Isaac Boxtel has stolen the black tulip in her room, she is willing to pursue Isaac Boxtel to Haarlem. She cannot take it for granted that the tulip is stolen by Isaac Boxtel known as Jacob in Dort and in Loevenstein.

She even dares to request The Prince and her father is moved to the fortress in Loevenstein. It is in order to see Van Baerle so often. "Oh, how I blessed His Highness in my heart. If God grants to him all the happiness that I have wished him, certainly Prince William will be the happiest man on earth" ( $p$ 127).

This mentions that Prince of Orange or William of Orange have such an important role to set free Cornelius Van Baerle. It is due to Rosa's feeling of love toward Van Baerle. Rosa loves Van Baerle, and she reveals the love directly within the conversation between Van Baerle and her in Loevenstein when they see each other after being apart. Rosa keeps trying to do the best for Van Baerle. It is in order to help Van Baerle with his bulbs of the black tulip. Rosa understands that Van Baerle really loves and cares the bulbs of the black tulip. Thus, Rosa is trying hard to take care of them. Moreover, she is willing to give such a great care for those bulbs for the sake of Van Baerle. "Teach me to read and to write. I shall make the best of your lessons, believe me; and, in this way, we shall never be separated any more except, by our own will" (p 134). Indeed, Rosa is a smart girl. She does not only love Van Baerle and his bulbs of black tulip dearly. She is even wants more about that. It seems that she does not want to be "used" only by Van Baerle. However, it is also one of the ways which allows her to keep contact with Van Baerle. "To speak to Cornelius of his tulip was an expedient resorted to by her to make him forget everything, even Rosa herself' (p 135).

Rosa feels offended and she feels that she is being used by Van Baerle. It is normal since he makes her to keep the bulbs, he makes her to look after the bulbs and he even makes her prepare all things for the sake of the tulip. Rosa is serious in looking after the tulip. "Rosa watched over the tulip as a mother over her child, or a dove over her eggs" ( $p$ 183). Even, Rosa is willing to go to Haarlem in order to mention that the true black tulip discoverer is Van Baerle. She does not realize that black tulip is being spoken in the town. She is ready to face and tell the truth in front of Van Herysen, the president of Horticulture in Haarlem and Prince of Orange. She sacrifices herself to face them although she gets accused of being too materialistic. "I think, Monsigneur, that the bait of a hundred thousand guilders may have tempted her" ( $p$ 204).

It is said by Van Herysen, the president of Horticulture Society of Haarlem. He thinks that Rosa is trying to pursue the money. She also tells the further explanation that she is not the black tulip' discoverer, but she just looks after it. "Well then, I am not an experienced florist; I am only a poor girl, one of the people, who, three months ago, knew neither how to read or to write. No, the black tulip has not been found by myself" ( $p$ 206). She explains more that Van Baerle, the prisoner of the town produces the black tulip and now he is in Loevenstein. She also adds some chronological information about the black tulip. Thus, Van Baerle and Rosa win the contest. She is not really materialistic, however materialism in 
her appears and it is blended with the feeling of love to Van Baerle. She knows that the tulip is not common tulip thus she is willing to pursue the recognition in order to get the black tulip and getting the love of Cornelius Van Baerle as well.

\section{Gryphus}

Materialism attitude owned by Gryphus is that his attitude to the prisoner. $\mathrm{He}$ is not a kind of easy prison keeper who is easily bribed, as it is seen when Van Baerle helps him when he gets broken arm. It does not move either his heart or his attitude in treating Van Baerle as the prisoner. In fact, his rudeness toward the prisoners has some possibilities. First one, it is his trait as a prison keeper and it is his natural behavior to do such things to the prisoners. The second one, it is possible that his attitude is a form of his loyalty toward his duty since if he does not do such things he will be given some penalties. Thus, he does that way, and surely he is such a cruel jailer in order to obey the government. By being bad to the prisoners, as people know that prisoners are considered as the men who act against the law of countries. Therefore, it is not something wrong when Gryphus treats all of the prisoners badly since they are bad for the nations.

\section{Different Level of Materialism among the Main Characters}

Van Baerle is considered to be materialistic in the analysis of the novel. Indeed he is a very rich man, however; his abundant love toward black tulip makes him everything is less important than black tulip. He is also attracted with the grant which is a hundred thousand guilders. He mentions black tulip over and over. Moreover, Van Baerle makes Rosa as the bridge between his black tulip and he. He treats love as secondary needs after the black tulip. However, Van Baerle has materialistic based on human basic need character since he still appreciates the law of religion, aesthetic, as well as moral. Meanwhile, the materialism level between Van Baerle and Isaac Boxtel is indeed different. Isaac Boxtel is trying to put all his effort in order to gain the recognition as a first black tulip discoverer and being granted a hundred thousand guilders. He is brave enough to do wrong things based on common society, that is stealing others' belonging, that is why he is considered as a person who has money-oriented materialistic.

Rosa is indeed materialistic as well. However, the way she is materialistic is different from Isaac Boxtel. Rosa is trying to help Van Baerle in obtaining black tulip which will be granted a hundred thousand guilders. Indeed, at glance her materialistic attitude does not appear clearly. By approaching Van Baerle, Rosa can get a hundred thousand guilder as well. Rosa's way is actually different from Van Baerle and Isaac Boxtel. Van Baerle is materialistic although he is very rich, but he puts his effort in a good way, without stealing. However, Rosa's way is also different from Isaac Boxtel since Isaac Boxtel tries to steal the bulb of the black tulip. Gryphus is also materialistic, he is materialistic since he is trying to be cruel to all of his prisoners. It is because he is afraid if he loses his job as a prison keeper. Van Baerle, Gryphus, and Rosa actually have the same level of materialistic attitude that is materialistic based on human basic need. 